\title{
Bentonite Effects on Zinc Concentration in Plants Irrigated with Wastewater
}

\author{
Gilvanise Alves Tito ${ }^{1}$, Lúcia Helena Garófalo Chaves $^{1 *}$, Francisco De Assis Santos e Silva ${ }^{2}$ \\ ${ }^{1}$ Department of Agricultural Engineering, Federal University of Campina Grande, Campina Grande, Brazil \\ ${ }^{2}$ Department of Food Engineering, Federal University of Campina Grande, Campina Grande, Brazil \\ Email: *lhgarofalo@hotmail.com
}

How to cite this paper: Tito, G.A., Chaves, L.H.G. and Silva, F.A.S. (2017) Bentonite Effects on Zinc Concentration in Plants Irrigated with Wastewater. American Journal of Plant Sciences, 8, 2433-2444. https://doi.org/10.4236/ajps.2017.810165

Received: August 21, 2017

Accepted: September 12, 2017

Published: September 15, 2017

Copyright () 2017 by authors and Scientific Research Publishing Inc. This work is licensed under the Creative Commons Attribution International License (CC BY 4.0).

http://creativecommons.org/licenses/by/4.0/ (c) (i) Open Access

\begin{abstract}
A greenhouse study was conducted to investigate the effect of bentonite on zinc concentrations in radish and corn irrigated with wastewater. The experimental units were plastic pots with a capacity of $5 \mathrm{~kg}$ and $14 \mathrm{~kg}$ for radish and corn, respectively. The soil was mixed with increasing doses of bentonite equivalent to $0,30,60$ and $90 \mathrm{t} \cdot \mathrm{ha}^{-1}$. The plants were irrigated with poor quality water with a concentration of $5 \mathrm{mg} \cdot \mathrm{L}^{-1} \mathrm{Zn}$. On the occasion of the harvest of radish and corn, that is, at 30 and 60 days after the emergence, respectively, the plants were separated in aerial part and roots, dried in a forced circulation oven, weighed and ground for analysis of zinc in the plant tissues. After these analyzes, the translocation factor $(T F)$, the translocation index $(T I)$, the bioaccumulation in the plant $(B F P)$ and in the root $(B F R)$ were calculated. According to the conditions of this research, the incorporation of bentonite to the soil irrigated with water of inferior quality favored the development of radish and corn; allowed the retention of the $\mathrm{Zn}$ metal in the soil, reducing the concentrations of this metal in the root of the radish and in the aerial part of the corn; decreased the transfer of zinc from the soil to the plants under study.
\end{abstract}

\section{Keywords}

Heavy Metals, Corn, Radish, Remediation, Clay, Translocação, Bioaccumulation

\section{Introduction}

In view of the large consumption of water in irrigated crops and the scarcity of water in certain regions, it is essential to use it rationally and avoid waste. Thus the reuse of water has taken up considerable importance. Wastewater has beneficial effects on crops, both as a source of water and as a source of nutrients for 
plants. However, the use of this water can contribute to the accumulation of heavy metals in the soil, if they have metallic ions even in small concentrations.

Among the factors that influence the concentration of heavy metals on and within plants, the most important are the nature of the soil on which the plant is grown, and the application of fertilizers, sewage sludge or irrigation with wastewater. This water being used in crop irrigation may not only result in soil contamination, i.e., contamination environmental due to the accumulation of this metal, but lead to elevated heavy metal uptook by crops, which may affect food quality and safety [1]. According to Cambra et al. [2], soil contaminated with metals is a primary route of toxic element exposure to humans. Toxic metals can enter the human body by consumption of contaminated food crops, water or inhalation of dust.

Heavy metal, such as, zinc, is essential for normal body growth and functions of living organisms and is referred to as essential elements [3]. This element, detected in the wastewater, may come from petrochemicals industries, sewage, trash, among other sources, for example, the use of zinc-based fertilizers such as zinc oxide, zinc sulfate, zinc nitrate and zinc chloride.

The ability of a metal species to migrate from the soil into plant tissues is referred to as bioaccumulation factor (BF). It is calculated as a ratio of concentration of a specific metal in plant tissue to the concentration of the same metal in soil, both represented in the same units [4]. Higher BF values $(\geq 1)$ indicate higher absorption of metal from soil by the plant and higher suitability of the plant for phytoextraction and phytoremediation. On the contrary, lower values indicate poor response of plants towards metal absorption and the plant can be used for human consumption [5].

The maximum tolerable value for vegetables, roots and tubers and other fresh foods, according to Brazilian legislation for the zinc element is $50 \mathrm{mg} \cdot \mathrm{kg}^{-1}$ [6]. However, the heavy metal contents in the dry matter causing symptoms of plant phytotoxicity are $70-400 \mathrm{mg} \cdot \mathrm{kg}^{-1}[7]$.

For treatment of wastewater there are several technologies, and among these, adsorption of heavy metal is an effective method. Recent studies have emphasized the efficiency of zeolite and bentonite in the immobilization of heavy metals by the adsorption method, minimizing contamination by these metals in soils and waters [8] [9]. Sheta et al. [10] found that zeolite and bentonite have a high $\mathrm{Zn}$ and Fe retention potential.

Bentonite, found in large quantities in the municipality of Boa Vista, State of Paraíba, is predominantly composed of clay minerals from the group of smectite and quartz impurities. Some varieties are also composed of kaolinite and ilite [11]. The bentonite material, from the Primavera deposit, of inferior quality, has been studied for a long time as a soil conditioner, mainly by adsorbing heavy metals. The results of these studies have shown favorable effects both on the adsorption of these metals and on the chemical and physical properties of the soils [12]. 
The efficiency of each clay-mineral in removing the metal cations from the soil/effluent systems should be evaluated for each of these cations separately. Thus, this research aimed to study the effect of bentonite on zinc concentrations in radish and corn irrigated with wastewater.

\section{Material and Methods}

This experiment was carried out in a greenhouse at the Agricultural Engineering Department, Federal University of Campina Grande, Paraiba, Brazil, using soil samples collected in the superficial layer $(0-20 \mathrm{~cm})$ of Eutrophic Red Latosol [13]. These samples were air-dried, crushed, sieved through a $2 \mathrm{~mm}$ sieve and chemically characterized according to [14] presenting the following attributes: $\mathrm{pH}\left(\mathrm{H}_{2} \mathrm{O}\right)=6.0$; electrical conductivity $=0.16 \mathrm{mmhos} \cdot \mathrm{cm}^{-1} ; \mathrm{Ca}=2.10 \mathrm{cmolc} \cdot \mathrm{kg}^{-1}$; $\mathrm{Mg}=2.57 \mathrm{cmolc} \mathrm{kg}{ }^{-1} ; \mathrm{Na}=0.06 \mathrm{cmolc} \cdot \mathrm{kg}^{-1} ; \mathrm{K}=0.14 \mathrm{cmolc} \cdot \mathrm{kg}^{-1} ; \mathrm{H}+\mathrm{Al}=1.78$ cmolc. $\mathrm{kg}^{-1}$; organic carbon $=5.5 \mathrm{~g} \cdot \mathrm{kg}^{-1} ; \mathrm{P}=45.0 \mathrm{mg} \cdot \mathrm{kg}^{-1}$ and $\mathrm{Zn}=14.16$ $\mathrm{mg} \cdot \mathrm{kg}^{-1}$.

The bentonite clay samples collected in the Primavera mine, Paraiba State, Brazil, were air dried and sieved with $0.074 \mathrm{~mm}$ mesh in order to precede X-ray diffraction analysis. According to this analysis bentonite samples, presents picks of smectite clays, of tridymite (a silicate mineral and polymorph of high temperature of quartz) and of quartz (low quantity).

The two independent experiments, that is, for each plant (radish and corn) consisted of four doses of bentonite $0,30,60$ and $90 \mathrm{t} \cdot \mathrm{ha}^{-1}$ corresponding to 10.7, 21.4 and $32.1 \mathrm{~g} \cdot \mathrm{kg}^{-1}$ of soil, with four replications, in a completely randomized design.

Initially, during the conduction of the experiments, the soil was dried, sieved and mixed with the dose of bentonite corresponding to the treatments. The mixtures of soil with bentonite were conditioned in plastic vessels, placed in field capacity with water supply and incubated for 20 days. Planting fertilization was carried out, according to Novais et al. [15], so as to provide in the vessels of 5 and $14 \mathrm{~kg}$ of soil, cultivated with radish (Raphanus sativus) and maize (Zea mays L.), respectively, 1.11 and $3.11 \mathrm{~g}$ of urea at 1.25 and $3.5 \mathrm{~g}$ of potassium chloride $(\mathrm{KCl})$ and 8.3 and $23.33 \mathrm{~g}$ of single superphosphate $\left(\mathrm{P}_{2} \mathrm{O}_{5}\right)$, respectively. Then, the sowing was done, in each experimental unit, according to the cultures. After 8 days of emergence, thinning was done, leaving two plants per experimental unit and beginning irrigation with water of inferior quality. The concentration of zinc contained in the water used was $5 \mathrm{mg} \cdot \mathrm{L}^{-1}$, resulting in a cumulative concentration in the soil for cultivation of radish and of 6.0 and $13.04 \mathrm{mg} \cdot \mathrm{kg}^{-1}$ of $\mathrm{Zn}$, respectively, at the end of the cycle of each culture.

On the occasion of the harvest of radish and corn, that is, at 30 and 60 days after the emergence of the plants, respectively, the plants were separated in aerial part and roots, washed in distilled and deionized water and dried in a forced circulation oven at $65^{\circ} \mathrm{C}$ in paper bags until constant weight and, the dry biomass of the shoots (DBS) and roots (DMR) were subsequently weighed. The- 
reafter the dried material was milled for analysis of the plant tissues. These tissues $(0.3 \mathrm{~g})$ were digested using $\mathrm{HNO}_{3}(8 \mathrm{ml})$ and $\mathrm{HClO}_{4}(6 \mathrm{ml})$ i.e., nitroperchloric digestion (3:1) [14]. After the digestion, $\mathrm{Zn}$ concentration in plant tissue was analyzed by plasma mass spectrometry (ICP-OES) according to the methodology performed by Oliva et al. [16].

The amount of zinc accumulated in the shoots $(A S)$ and roots $(A R)$ of the plant (mg/pot) was calculated according to Equation (1).

$A S$ or $A R\left(\frac{\mathrm{mg}}{\text { pot }}\right)=\frac{[\text { dry biomass of the shoots }(\mathrm{g}) \text { or of roots }(\mathrm{g})] \times[\text { concentration of element }(\mathrm{mg} / \mathrm{kg})]}{1000}$

The translocation factor $(T F)$ gives the leaf/root zinc concentration and depicts the ability of the plant to translocate the metal species from roots to leaves (shoot) at different concentrations. This index was calculated according to Equation (2) [17].

$$
T F=\frac{\text { zinc concentration in the shoot }(\mathrm{mg} / \mathrm{kg})}{\text { zinc concentration in the root }(\mathrm{mg} / \mathrm{kg})}
$$

The translocation index ( $T I$ ) was determined according to Equation (3) [18].

$$
T I=\frac{A S}{\text { amount of } \mathrm{Zn} \text { accumulated in the complete plant }} \times 100
$$

The bioaccumulation factor $(B F)$, an index of the ability of the plant to accumulate a particular metal with respect to its concentration in the soil substrate [19], was calculated according to Equation (4) or Equation (5).

$$
\begin{gathered}
B F P=\frac{\text { zinc concentration in the complete plant }(\mathrm{mg} / \mathrm{kg})}{\text { zinc concentration in the soil }(\mathrm{mg} / \mathrm{kg})} \\
B F R=\frac{\text { zincconcentration in the plant root }(\mathrm{mg} / \mathrm{kg})}{\text { zinc concentration in the soil }(\mathrm{mg} / \mathrm{kg})}
\end{gathered}
$$

The Assistat Software version 7.7 [20] was employed to analyze the obtained results, by using the F test and regression polynomials, which were used to adjust the data when significant.

\section{Results and Discussion}

Radish dry root biomass (DBR), ranging from $1.79 \mathrm{~g}$ ( $0 \mathrm{t} \cdot \mathrm{ha}^{-1}$ of bentonite) to $2.72 \mathrm{~g}$ (90 thha ${ }^{-1}$ of bentonite), was influenced by the doses of bentonite (Table 1 ), corresponding to an increase of $51.56 \%$ of the highest dose relative to the control (Figure 1(a)).

In the case of corn, application of bentonite to the soil resulted in an increase of root dry weight of around 3.14\% (Figure 1(b)) corroborating [21] who found that bentonite and zeolite mixed with soil provided an increase in biomass and corn and bean crop development. Similarly, Youssef [22] working with these clays verified a significant increase in growth, productivity and chemical composition of potato (Solanum tuberosum L.). 
Table 1. Summary of the analyses of variance for the dry biomass of the shoots (DBS) and root part (DBR) of the radish and corn irrigated with lower quality water with increasing doses of bentonite.

\begin{tabular}{cccccc}
\hline & & \multicolumn{5}{c}{ Mean Squares } \\
\cline { 3 - 6 } Source of Variation & DF & \multicolumn{2}{c}{ Radish } & \multicolumn{2}{c}{ Corn } \\
\cline { 3 - 6 } & & DBS & DBR & DBS & DBR \\
\cline { 3 - 6 } & 3 & $0.04 \mathrm{~ns}$ & $0.70^{* *}$ & $73.03 \mathrm{~ns}$ & $6.87 \mathrm{~ns}$ \\
Bentonite & 1 & $0.02 \mathrm{~ns}$ & $1.88^{* *}$ & $70.16 \mathrm{~ns}$ & $18.65^{*}$ \\
Linear & 1 & $0.01 \mathrm{~ns}$ & $0.14 \mathrm{~ns}$ & $41.15 \mathrm{~ns}$ & $0.38 \mathrm{~ns}$ \\
Quadratic & 12 & 0.13 & 0.07 & 25.91 & 2.45 \\
Error & & 12.27 & 11.67 & 5.71 & 7.08 \\
VC (\%) & & 2.94 & 2.26 & 89.21 & 22.10 \\
Mean $(\mathrm{g})$ & & &
\end{tabular}

$\mathrm{DF}=$ Degree of Freedom, ns, ${ }^{*}$ and ${ }^{* *}$ no significant, significant at $5 \%$ and $1 \%$ level, respectively. VC $=$ Variation Coefficient.

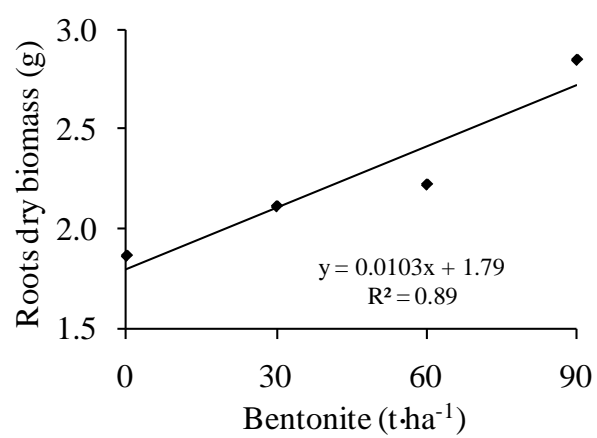

(a)

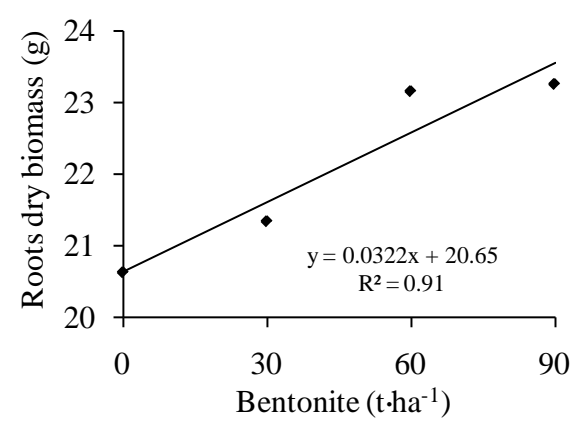

(b)

Figure 1. Dry biomass of the radish (a) and corn (b) roots irrigated with lower quality water, due to increasing doses of bentonite.

The significant effect of the addition of bentonite to the soil in the development of several plants may be due to its positive effect on the cation exchange capacity (CEC), thus favoring the release of nutrients to the plant. Bentonite, according to Marschner [23], also performs as a fertilizer, increasing micronutrients and macronutrients in soil as well as other biochemical processes related to plant growth.

The concentration of $\mathrm{Zn}$ in radish roots, which was significantly influenced by the doses of bentonite (Table 2), ranged from 75.49 to $48.28 \mathrm{mg} \cdot \mathrm{kg}^{-1}$, reducing the order by $36.04 \%$ when comparing the control with the highest dose (Figure $2(a))$.

The average concentration of zinc in roots of radish (Table 2) is above the tolerable maximum value for human consumption of vegetables, roots and tubers and other fresh foods which is $50 \mathrm{mg} \cdot \mathrm{kg}^{-1}$ of zinc [6].

It is important to emphasize that this culture was irrigated with water having zinc in the maximum concentration allowed to discharge effluents. Even so, it is 
Table 2. Summary of the analysis of variance of zinc concentration in the shoot (CS) and zinc concentration in the root $(\mathrm{CR})$ of radish and corn, irrigated with lower quality water with increasing doses of bentonite.

\begin{tabular}{cccccc}
\hline & & \multicolumn{5}{c}{ Mean Squares } \\
\cline { 3 - 6 } Source of Variation & DF & \multicolumn{2}{c}{ Radish } & \multicolumn{2}{c}{ Corn } \\
\cline { 3 - 6 } & & CS & CR & CS & CR \\
\cline { 3 - 6 } Bentonite & 3 & $43.32 \mathrm{~ns}$ & $730.95^{* *}$ & $310.49 \mathrm{~ns}$ & $28.60 \mathrm{~ns}$ \\
Linear & 1 & $100.35 \mathrm{~ns}$ & $1678.11^{* *}$ & $879.14^{*}$ & $82.42 \mathrm{~ns}$ \\
Quadratic & 1 & $25.00 \mathrm{~ns}$ & $416.16^{*}$ & $42.25 \mathrm{~ns}$ & $1.69 \mathrm{~ns}$ \\
Error & 12 & 4.61 & 49.95 & 97.51 & 72.01 \\
VC (\%) & & 14.08 & 12.48 & 16.04 & 13.34 \\
Mean $\left(\mathrm{mg} \cdot \mathrm{kg}^{-1}\right)$ & & 46.35 & 56.65 & 61.57 & 63.62 \\
\hline
\end{tabular}

$\mathrm{DF}=$ Degree of Freedom, ns, ${ }^{*}$ and ${ }^{* *}$ no significant, significant to the $5 \%$ and $1 \%$ level, respectively. $\mathrm{VC}=$ Variation Coefficient.

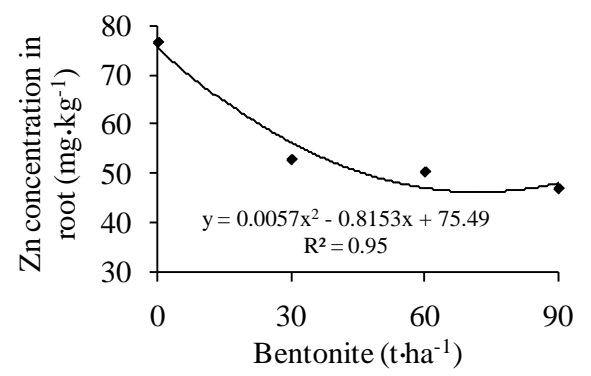

(a)

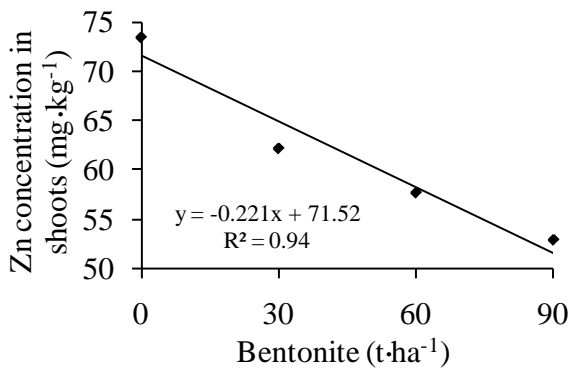

(b)

Figure 2. Zinc concentration in the root of radishes (a) and in the shoots of corn (b) in function of increasing doses of bentonite.

worrying the consumption of food products irrigated with water of inferior quality, with the presence of this metal, since this metal and others participate in the food chain [24] [25].

Plants grown in soils irrigated with wastewater contaminated with heavy metals can cause great risk to human health [1] [26] [27]. However, at the $90 \mathrm{t} \cdot \mathrm{ha}^{-1}$ dose of bentonite, the concentration was $42.91 \mathrm{mg} \cdot \mathrm{kg}^{-1}$, i.e., less than the maximum tolerable value for human consumption, showing the beneficial effect of the bentonite incorporation into the soil.

The application of bentonite to the soil influenced the concentration of $\mathrm{Zn}$ in the aerial part (CS) of the corn, with a reduction of $27.81 \%$ in this concentration when the control was compared with the highest dose (Figure 2(b)). However, this reduction, in this case, was not effective enough to make the concentration below the maximum tolerable, contrary to what was observed by Khan et al. [28]. These authors, studying soil contamination by heavy metals through irrigation with water containing heavy metals and uptake of these metals by food crops, found that the concentration in the soil and in the edible parts of plants for zinc 
were below the allowable limits $\left(100 \mathrm{mg} \cdot \mathrm{kg}^{-1}\right)$ according to the State Environmental Protection Administration (SEPA) in China, in the cultures Raphanus sativus L., Zea mays, Brassica juncea L., Brassica oleracea L., Brassica napus and Lactuca sativa L.

The amount zinc accumulated in the radish root $(A R)$ (Figure $3(\mathrm{a})$ ) had a quadratic behavior ranging from 0.139 to $0.094 \mathrm{mg} /$ pot, promoting a reduction of $32.26 \%$ as a function of increasing doses of bentonite, which means that the application of this clay to the soil was beneficial (Table 3).

In the case of corn, the bentonite incorporated into the soil promoted a reduction of $23.38 \%$ in the $\mathrm{Zn}$ accumulation in the aerial part of the crop (Figure $3(\mathrm{~b}))$.

By the analysis of variance (Table 4), the bentonite doses did not significantly influence the transfer factor of the $\mathrm{Zn}$ of the cultures, however the regression showed by the linear behavior, the significance in the culture of radish and corn (Figure 4). In the case of radish, the transfer factor of $\mathrm{Zn}$ ranged from 0.723 to 0.975 that is, an increase of $34.85 \%$, while in the corn, a decrease from 1.08 to 0.86 , around $20.04 \%$ was observed. Most TF values obtained for $\mathrm{Zn}$ in this study were less than 1.0 suggesting that roots may regulate the transport of $\mathrm{Zn}$ to shoots.

Bentonite applied to the soil had a significant effect, at a $5 \%$ probability level in $I T$ for corn (Table 4), showing a linear behavior (Figure 4) ranging from $82.01 \%$ to $75.92 \%$, that is, a reduction in the order of $7.42 \%$ when comparing the control with the highest dose. This reduction showed that the concentration of $\mathrm{Zn}$ in the aerial part, where the edible part of the corn is located, decreased, thus avoiding entry into the food chain.

The zinc bioaccumulation factor $(B F P)$ in the radish was significantly reduced in a quadratic manner $23.29 \%$ (Table 5) with the incorporation of bentonite doses varying from 3.01 to 2.31 of the control at the highest dose (Figure 5(a)). The BFP of corn reduced linearly around $24.29 \%$ (Figure 5(b)). Bentonite doses positively favored $B F R$ only for the radish reducing $38.93 \%$, according to Figure $5(c)$.

The BFP and $B F R$ values were higher than those observed by Mirecki et al. [29] that is, these authors found BF for corn from 0.1 to 0.2. Most BF values obtained

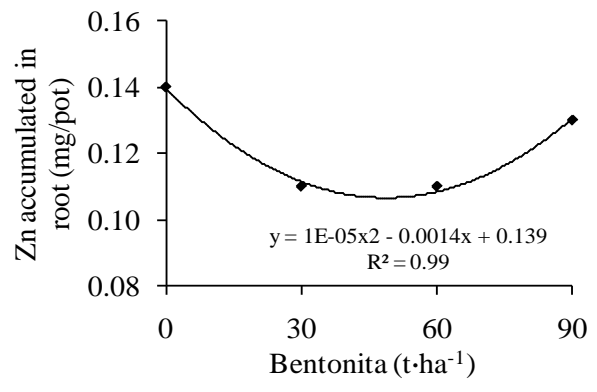

(a)

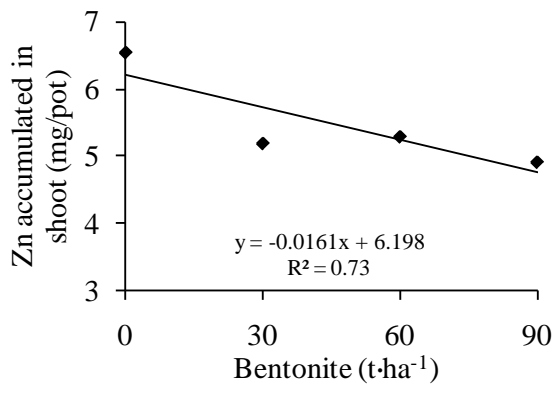

(b)

Figure 3. Zinc accumulated in root of radishes (a) and in shoot of corn (b), depending on dose increasing bentonite. 
Table 3. Summary of the analysis of variance of amount zinc accumulated in the shoot $(A S)$ and root $(A R)$ of radish and corn, irrigated with lower quality water with increasing doses of bentonite.

\begin{tabular}{|c|c|c|c|c|c|}
\hline \multirow{3}{*}{ Source of Variation } & \multirow{3}{*}{$\mathrm{DF}$} & \multicolumn{4}{|c|}{ Mean Squares } \\
\hline & & \multicolumn{2}{|c|}{ Radish } & \multicolumn{2}{|c|}{ Corn } \\
\hline & & $A S$ & $A R$ & $A S$ & $A R$ \\
\hline Bentonite & 3 & $0.0005 \mathrm{~ns}$ & $0.001 \mathrm{~ns}$ & $2.31 \mathrm{~ns}$ & $0.004 \mathrm{~ns}$ \\
\hline Linear & 1 & $0.0006 \mathrm{~ns}$ & $0.0001 \mathrm{~ns}$ & $4.65^{\star}$ & $0.005 \mathrm{~ns}$ \\
\hline Quadratic & 1 & $0.0004 \mathrm{~ns}$ & $0.003^{\star *}$ & $0.98 \mathrm{~ns}$ & $0.005 \mathrm{~ns}$ \\
\hline Error & 12 & 0.0006 & 0.0002 & 0.79 & 0.03 \\
\hline VC (\%) & & 17.71 & 12.34 & 16.21 & 11.95 \\
\hline Mean (mg/pot) & & 0.14 & 0.12 & 5.47 & 1.40 \\
\hline
\end{tabular}

$\mathrm{DF}=$ Degree of Freedom, ns, ${ }^{*}$ and ${ }^{* *}$ no significant, significant to the $5 \%$ and $1 \%$ level, respectively. VC $=$ Variation Coefficient.

Table 4. Summary of the analysis of variance of transfer factor $(T F)$ and translocation index (TI) of the $\mathrm{Zn}$ of the cultures radish and corn, irrigated with lower quality water with increasing doses of bentonite.

\begin{tabular}{cccccc}
\hline & & \multicolumn{4}{c}{ Mean Squares } \\
\cline { 3 - 6 } Source of Variation & DF & \multicolumn{2}{c}{ Transfer Factor $(T F)$} & \multicolumn{2}{c}{ Translocation Index $(T)$} \\
\cline { 3 - 6 } & & Radish & Corn & Radish & Corn \\
\hline Bentonite & 3 & $0.06 \mathrm{~ns}$ & $0.04 \mathrm{~ns}$ & $64.91 \mathrm{~ns}$ & $30.05^{*}$ \\
Linear & 1 & $0.13^{*}$ & $0.10^{*}$ & $51.14 \mathrm{~ns}$ & $82.18^{* *}$ \\
Quadratic & 1 & $0.09 \mathrm{~ns}$ & $0.01 \mathrm{~ns}$ & $122.77 \mathrm{~ns}$ & $3.40 \mathrm{~ns}$ \\
Erro & 12 & 0.02 & 0.02 & $43.92 \mathrm{~ns}$ & 6.61 \\
VC (\%) & & 17.98 & 14.49 & 12.92 & 3.26 \\
Mean & & 0.85 & 0.97 & $51.31 \%$ & $78.97 \%$ \\
\hline
\end{tabular}

$\mathrm{DF}=$ Degree of Freedom, ns, ${ }^{*}$ and ${ }^{\star *}$ no significant, significant to the $5 \%$ and $1 \%$ level, respectively. VC $=$ Variation Coefficient.

Table 5. Summary of the analyses of variance for bioaccumulation factor of zinc in plant $(B F P)$ and in roots $(B F R)$ of the radish and corn irrigated with poor quality water with increasing doses of bentonite.

\begin{tabular}{cccccc}
\hline & & \multicolumn{4}{c}{ Mean Squares } \\
\cline { 3 - 6 } Source of Variation & DF & \multicolumn{3}{c}{ BFP } & RFR \\
\cline { 3 - 6 } & & Radish & Corn & Radish & Corn \\
\hline Bentonite & 3 & $0.40^{*}$ & $0.31^{*}$ & $1.80^{* *}$ & $0.04 \mathrm{~ns}$ \\
Linear & 1 & $0.53 \mathrm{~ns}$ & $0.89^{*}$ & $4.13^{* *}$ & $0.11 \mathrm{~ns}$ \\
Quadratic & 1 & $0.65^{*}$ & $0.03 \mathrm{~ns}$ & $1.02^{*}$ & $0.002 \mathrm{~ns}$ \\
Erro & 12 & 0.11 & 0.11 & 0.12 & 0.10 \\
VC (\%) & & 13.05 & 14.36 & 12.48 & 13.34 \\
Mean (\%) & & 2.56 & 2.28 & 2.81 & 2.34 \\
\hline
\end{tabular}

$\mathrm{DF}=$ Degree of Freedom, ns, ${ }^{*}$ and ${ }^{*}$ no significant, significant at $5 \%$ and $1 \%$ level, respectively. $\mathrm{VC}=$ Variation Coefficient. 


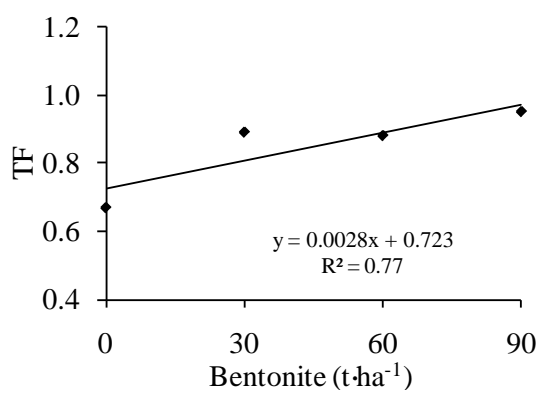

(a)

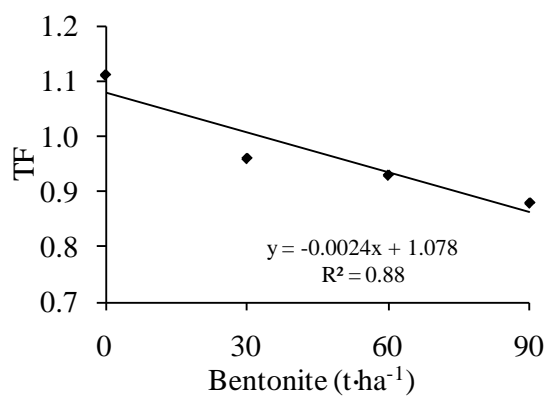

(b)

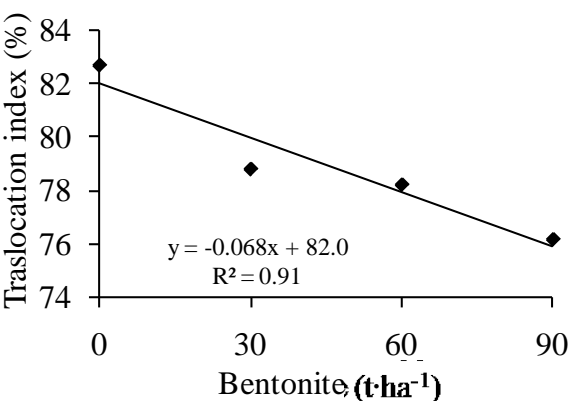

(c)

Figure 4. Translocation factor of the $\mathrm{Zn}$ of the cultures radish (a) and corn (b) and translocation index (c) in the corn depending on dose increasing bentonite.

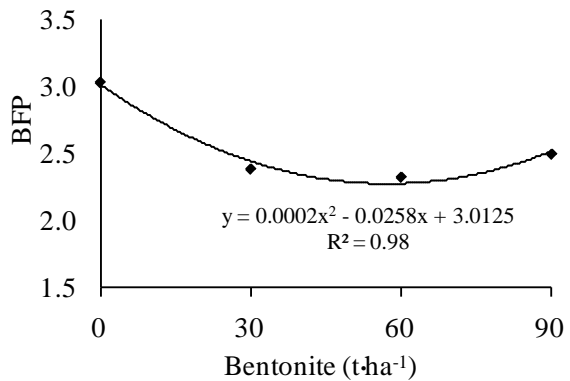

(a)

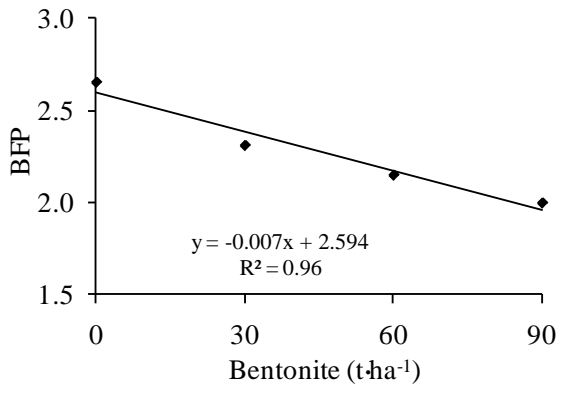

(c)

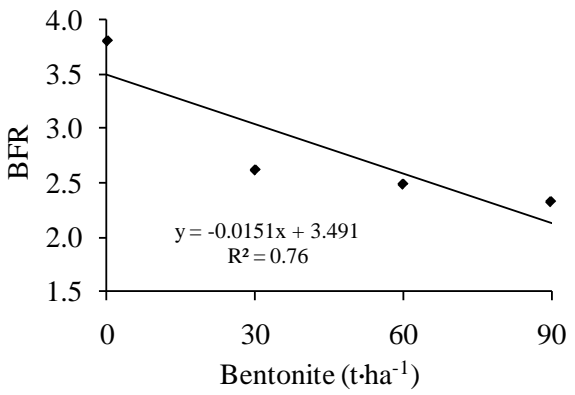

(d)

Figure 5. Bioaccumulation factor of zinc in plant (BFP) of radish (a) and corn (b) and bioaccumulation factor of zinc in root (BFR) of radish (c) depending on dose increasing bentonite.

for $\mathrm{Zn}$ in this study were higher than 1.0 indicating that this metal is easily taken up by plants and higher suitability of the plant for phytoextraction and phyto- 
remediation [4].

According to Sajjad et al. [30] if the transfer coefficient of a metal is greater than 0.5 , the plant will have a greater chance of the metal contamination by anthropogenic activities. However, the reductions in both $B F P$ and $B F R$ as a function of bentonite applied to the soil, were beneficial; due to the large surface area and high cation exchange capacity, this clay has a high adsorption potential of metallic cations, such as zinc, reducing the absorption of this element by the roots of the plants and consequently, reducing its transport to the edible part of the plant. These results had the same behavior in relation to the effect of bentonite in the removal of copper and cadmium of soil irrigated with low quality water [31] [32].

\section{Conclusion}

According to the conditions of this research, the incorporation of bentonite to the soil irrigated with water of inferior quality favored the development of radish and corn; allowed the retention of the $\mathrm{Zn}$ metal in the soil, reducing the concentrations of this metal in the root of the radish and in the aerial part of the corn; decreased the transfer of zinc from the soil to the plants under study.

\section{Acknowledgements}

Special thanks to the Coordination for the Superior Level Personal Improvement (CAPES) for the scholarship granted to the first author.

\section{References}

[1] Muchuweti, M., Birkett, J.W., Chinyanga, E., Zvauya, R., Scrimshaw, M.D. and Lester, J.N. (2006) Heavy Metal Content of Vegetables Irrigated with Mixtures of Wastewater and Sewage Sludge in Zimbabwe: Implications for Human Health. Agriculture, Ecosystems \& Environment, 112, 41-48. https://doi.org/10.1016/j.agee.2005.04.028

[2] Cambra, K., Martínez, T., Urzelai, A. and Alonso, E. (1999) Risk Analysis of a Farm Area near a Lead- and Cadmium-Contaminated Industrial Site. Soil Sediment Contamination: An International Journal, 8, 527-540. https://doi.org/10.1080/10588339991339450

[3] Koki, I.B., Bayero, A.S., Umar, A. and Yusuf, S. (2015) Health Risk Assessment of Heavy Metals in Water, Air, Soil and Fish. African Journal of Pure and Applied Chemistry, 9, 204-210. https://doi.org/10.5897/AJPAC2015.0654

[4] Rangnekar, S.S., Sahu, S.K., Pandit, G.G. and Gaikwad, V.B. (2013a) Study of Uptake of $\mathrm{Pb}$ and $\mathrm{Cd}$ by Three Nutritionally Important Indian Vegetables Grown in Artificially Contaminated Soils of Mumbai, India. International Research Journal of Environmental Sciences, 2, 1-5.

[5] Rangnekar, S.S., Sahu, S.K., Pandit, G.G. and Gaikwad, V.B. (2013b) Accumulation and Translocation of Nickel and Cobalt in Nutritionally Important Indian Vegetables Grown in Artificially Contaminated Soil of Mumbai, India. Research Journal of Agricultural and Forest Sciences, 1, 15-21.

[6] ABIA (Associação Brasileira das Indústrias da Alimentação) (1985) Compêndio da legislação dos alimentos. [Compendium of Food Legislation: Consolidation of Food 
Standards and Standards.] Abia, São Paulo.

[7] Marques, M.O., Melo, W.J. and Marques, T.A. (2002) Metais pesados e o uso de biossólidos na agricultura. [Heavy Metals and the Use of Biosolids in Agriculture.] In: Tsutiya, M.T., Comparini, J.B., Alem Sobrinho, P., Hespanhol, I., Carvalho, P.C.T., Melfi, A.J., Melo, W.J. and Marques, M.O., Eds., Biosolids in Agriculture, 2nd Edition, ABES/SP, São Paulo, 365-403.

[8] Mahabadi, A.A., Hajabbasi, M.A., Khademi, H. and Kazemian, H. (2007) Soil cádmium stabilization using an Iranian natural zeolite. [Soil Cadmium Stabilization Using an Iranian Natural Zeolite.] Geoderma, 137, 388-393. https://doi.org/10.1016/j.geoderma.2006.08.032

[9] Shi, W., Shao, H., Li, H., Shao, M. and Du, S. (2009) Progress in the Remediation of Hazardous Heavy Metal-Polluted Soils by Natural Zeolite. Journal of Hazardous Materials, 170, 1-6. https://doi.org/10.1016/j.jhazmat.2009.04.097

[10] Sheta, A.S., Falatah, A.M., Al-Sewailem, M.S., Khaled, E.M. and Sallam, A.S. (2003) Sorption Characteristics of Zinc and Iron by Natural Zeolite and Bentonite. Microporous and Mesoporous Materials, 61, 127-136. https://doi.org/10.1016/S1387-1811(03)00360-3

[11] Menezes, R.R., Souto, P.M., Santana, L.N.L., Neves, G.A., Kiminami, R.H.G.A. and Ferreira, H.C. (2009) Argilas bentoníticas de Cubati, Paraíba, Brasil: Caracterização física-mineralógica. [Bentonite Clay from Cubati, Paraíba, Brazil: Physical and Mineralogical Characterization.] Cerâmica, 55, 163-169. https://doi.org/10.1590/S0366-69132009000200008

[12] Tito, G.A., Chaves, L.H.G., Guerra, H.O.C. and Vasconcelos, A.C.F. (2016a) Bentonite. Agronomic Viewpoint of the Research Conducted in Brazil. LAP Lambert Academic Publishing, Saarbrücken, 120 p.

[13] Empresa Brasileira De Pesquisa Agropecuária-Embrapa. Centro Nacional de Pesquisa de Solos (2006) Sistema Brasileiro de Classificação de Solos. [Brazilian System of Soil Classification.] 2nd Edition, Embrapa Solos, Rio de Janeiro, 164 p.

[14] Empresa Brasileira De Pesquisa Agropecuária-Embrapa. Centro Nacional de Pesquisa de Solos (1997) Manual de métodos de análise de solo. [Manual of Soil Analysis Methods.] 2nd Edition, Embrapa Solos, Rio de Janeiro, 212 p.

[15] Novais, R.F., Neves, J.C.L. and Barros, N.F. (1991) Ensaio em ambiente controlado. [Controlled Environment Test.] In: Oliveira, A.J., Ed., Methods of Research in Soil Fertility, Embrapa-SEA, Brasília, 189-253.

[16] Oliva, S.R., Raitio, H. and Mingorance, M.D. (2003) Comparison of Two Wet Digestion Procedures for Multi-Element Analysis of Plant Samples. Communications in Soil Science and Plant Analysis, 34, 2913-2923. https://doi.org/10.1081/CSS-120025216

[17] Gupta, S., Nayek, S., Saha, R.N. and Satpati, S. (2008) Assessment of Heavy Metal Accumulation in Macrophyte, Agricultural Soil and Crop Plants Adjacent to Discharge Zone of Sponge Iron Factory. Environmental Geology, 55, 731-739. https://doi.org/10.1007/s00254-007-1025-y

[18] Abichequer, A.D. and Bohnen, H. (1998) Eficiência de absorção, translocação e utilização de fósforo por variedades de trigo. [Efficiency of Phosphorus Uptake, Translocation and Utilization in Wheat Varieties.] RevistaBrasileira de Ciência do Solo, 22, 21-26. https://doi.org/10.1590/S0100-06831998000100003

[19] Ghosh, M. and Singh, S.P. (2005) A Comparative Study of Cadmium Phytoextraction by Accumulator and Weed Species. Environmental Pollution, 133, 365-371. https://doi.org/10.1016/j.envpol.2004.05.015 
[20] Silva, F.A.S. and Azevedo, C.A.V. (2016) The Assistat Software Version 7.7 and Its Use in the Analysis of Experimental Data. African Journal of Agricultural Research, 11, 3733-3740. https://doi.org/10.5897/AJAR2016.11522

[21] Hassan, A.Z.A. and Mahmoud, A.W.M. (2013) The Combined Effect of Bentonite and Natural Zeolite on Sandy Soil Properties and Productivity of Some Crops. Top class Journal of Agricultural Research, 1, 22-28.

[22] Youssef, S.B.D. (2013) Effect of Bentonite and zeolite Ores on Potato Crop (Solanum tuberosum L.) under North Sinai Conditions. Journal Plant Production, 4, 1843-1856.

[23] Marschner, H. (1995) Mineral Nutrition of Higher Plants. Academic Press, San Diego, $889 \mathrm{p}$.

[24] Kumar, P.S., Ramalingam, S., Sathyaaselvabala, V., Kirupha, S.D., Murugesan, A. and Sivanesan, S. (2012) Removal of Cd(II) from Aqueous Solution by Agricultural Waste Cashew Nut Shell. Korean Journal of Chemical Engineering, 29, 756-768. https://doi.org/10.1007/s11814-011-0259-2

[25] Marin, A.B.P., Aguilar, M.I., Ortuno, J.F., Meseguer, V.F., Saez, J. and Florenz, M. (2010) Biosorption of $\mathrm{Zn}$ (II) by Orange Waste in Batch and Packed Bed Systems. Journal of Chemical Technology and Biotechnology, 85, 1310-1318. https://doi.org/10.1002/jctb.2432

[26] Liu, W., Zhao, J., Ouyang, Z., Söderlund, L. and Liu, G. (2005) Impacts of Sewage Irrigation on Heavy Metal Distribution and Contamination in Beijing, China. Environment International, 31, 805-812. https://doi.org/10.1016/j.envint.2005.05.042

[27] Sharma, R.K., Agrawal, M. and Marshall, F. (2007) Heavy Metal Contamination of Soil and Vegetables in Suburban Areas of Varanasi, India. Ecotoxicology and Environmental Safety, 66, 258-266. https://doi.org/10.1016/j.ecoenv.2005.11.007

[28] Khan, S., Cao, Q., Zheng, Y.M., Huang, Y.Z. and Zhu, Y.G. (2008) Health Risks of Heavy Metals in Contaminated Soils and Food Crops Irrigated with Wastewater in Beijing, China. Environmental Pollution, 152, 686-692. https://doi.org/10.1016/j.envpol.2007.06.056

[29] Mirecki, N., Agič, R., Šunić, L., Milenković, L. and Ilić, Z.S. (2015) Transfer Factor as Indicator of Heavy Metals Content in Plants. Fresenius Environmental Bulletin, 24, 4212-4219.

[30] Sajjad, K., Farooq, R., Shahbaz, S., Khan, M.A. and Sadique, M. (2009) Health Risk Assessment of Heavy Metals for Population via Consumption of Vegetables. World Applied Sciences Journal, 6, 1602-1606.

[31] Tito, G.A., Chaves, L.H.G., Vasconcelos, A.C.F. and Fernandes, J.D. (2016b) Bentonite Effect on Copper Adsorption on Plants Irrigated with Low Quality Water. International Journal of Current Research, 8, 41598-41604.

[32] Tito, G.A., Chaves, L.H.G., Fernandes, J.D. and Silva, F.A.S. (2017) Removal of Cadmium (Cd) from Low Quality Water by Bentonite Applied in the Soil. Australian Journal of Crop Science, 11, 596-604.

https://doi.org/10.21475/ajcs.17.11.05.p419 
Submit or recommend next manuscript to SCIRP and we will provide best service for you:

Accepting pre-submission inquiries through Email, Facebook, LinkedIn, Twitter, etc. A wide selection of journals (inclusive of 9 subjects, more than 200 journals)

Providing 24-hour high-quality service

User-friendly online submission system

Fair and swift peer-review system

Efficient typesetting and proofreading procedure

Display of the result of downloads and visits, as well as the number of cited articles Maximum dissemination of your research work

Submit your manuscript at: http://papersubmission.scirp.org/

Or contact ajps@scirp.org 